\title{
Adopting the Development of Course Delivery Approach towards Active Learning Based on the Utilization of Technology and Web Based Accounting Education
}

\author{
Amahi, Fidelis Uchechukwu \\ College of Education Agbor Delta State, Nigeria \\ fidelis_amahi@yahoo.com
}

\begin{abstract}
Over the years, accounting students and lecturers have been grappling with the challenges of achieving better results arising from the traditional approach of teaching which is passive, and lecture and lecturer - centred. This has not been very effective as the traditional course delivery mode or approach is being adopted. As the world is becoming a global village, it demands/requires new and improved methods to enhance students needed skills, competencies and knowledge expected of them by employers and modern day technologically equipped offices. The paper focuses on information and web based technologies in teaching accounting courses and their usefulness in improving students learning. The mean, standard deviation and $\mathrm{t}$ - test was used to analyse the data e generated in the study. The findings show that Information and Web Based Technologies would be relevant and bring about individualized student learning, enhance understanding, better skill and competencies acquisition and ensure accurate record retrieval for the global world and would be the basis for curriculum review and retraining of teachers for better course delivery based on Information and Web Based Technologies.
\end{abstract}

Keywords: information technology, web based technology, course delivery and active learning

\section{Introduction}

Accounting courses like other numerical related courses are assumed /perceived by students to be difficult. Efforts are being made by the teachers of accounting courses to bring more/better understanding of the course content to the recipients (students). With the advancement and wave of information technology resulting in the rapid growth in the fields of knowledge and making the world becoming a global village, the era of teaching accounting courses in our tertiary institutions using only the traditional approach where students are passive listeners, eagerly willing to copy solved questions should be a thing of the pasta retrospective cursory look at the accounting instructional methods shows that instruction delivery mode was mainly talk and chalk with occasional use of flip chart on an audio visual equipment such as filmstrips, projectors, and movies, videotapes. But it was not until 1990s that computer technology rapidly developed to the extent that computer applications like presentation tools which help enhance education delivery and the greatest boost, the worldwide web (www), which opened the gate. In Nigeria, accounting education is dependent on face-to- face chalk and talk one way communication teaching approach. Hardly do the lecturers make use of the common overhead projectors. Ashraf (2004) asserts that the approach is an ineffective teaching mode. This is corroborated by Smith and Rupp (2004) in their finding that on line courses made students have higher grades than traditional classroom courses.

Ali in Iheonunekwu, Onyinye and Nweze (2008), posits that Information technology (IT) is the "Physical structure of network of computers based systems (hardware, software and media) for purposes of organizing, processing, communicating, accessing, presenting, storing, retrieving and simplifying information. Amahi and Uge (2004) citing American Accounting Association (1966) define accounting as "the process of identifying, measuring and communicating economic information to permit informed judgements and decisions by use of information to permit informed judgments and decisions by users of information". With IT, financial data are collected, analysed, measured recorded and reported to users of the information for decision-making.

\section{Technology and Accounting}

It has been observed that traditional teaching approach is not very effective (Ashraf, 2004). Therefore to bring about effectiveness in the delivery mode of accounting courses, the means of delivery through IT should be adopted in line with the College of Business and Economics of the United Arab Emirates University (UAEU), United Arab Emirate, where the approach used to deliver all the accounting courses 
offered by the CBE was to enforce the active learning methodology and e-learning environment using specific active learning techniques in the course delivery. E-learning has been defined by many authorities. Urdan and Weggen in Al-soraiey - Algahtani Awadh (2010) define it as "the delivery of content via all electronic media, including the internet, intranet, extranets, satellite broadcast, audio / video tape, interactive TV and CD ROM". Khan (2005) defines it as "an innovative approach for delivering well designed, learner - centred, interactive and facilitated learning environment to anyone, anyplace, anytime by utilising the attributes and resources of various digital technologies along with other forms of learning material suited for open, flexible and distributed learning environment". Meyen et al in Alsoraiey Algahtani Awadh (2010) see it as "the acquisition and use of knowledge distributed and facilitated by electronic means". This goes to show that such acquisition and use of knowledge depend on the electronic media for communication between teachers and students, between learners themselves and between learners and the school.

From the foregoing the course delivery approach may be instructor - led (synchronous e-learning) or self-paced individual study (asynchronous e-learning). Bruff, Dean and Nola (2004) and Akpotowho and Ugeh (2007) agree that the use of online services (IT) in teaching and learning may bring a positive shift in the ability of the university to deliver reality to that which is expected and one which detracts from the integrity of the university. In the same vein Scheines, Lienhardt and Cho (2005) assert that the availability of information technology makes students do better in online version of their courses than the traditional passive lecture approach due to frequent voluntary engagement with interactive comprehension checks. Continuing they posit that without the influence of the lecturers, tutors and gender students who attended lectures did not perform as well as those who replaced lectures with online modules. Also through the rich discussion on-line a quiet introverted person can be pulled out of his shell much more efficiently than through the traditional approach (Smith and Rapp, 2004). It has been reported by researchers and educators in accounting education that the educational process is enhanced by the use of IT in classroom (David, McCracken and Reckers, 2003). According to the American Institute of Certified Public Accountants (AICPA 1999) the curriculum of accounting be revised to include IT as lecturers, and instructors who use technology, during teaching, assist students to master accounting content and develop technical literary. In a study on the faculty use of instructional technology, Peluchette and Rust in Absel-Azim (2006) concluded that most faculties preferred the use of the following technology in this order overhead transparencies, overhead projector, Power Point, blackboard or whiteboard, because they enhance their teaching effectiveness.

Relevance of Technology to Accounting Education: IT has become an essential tool in teaching accounting especially in view of the increasing globalization of accounting standards and practices. Using technology to teach will reduce cost while getting across to many recipients with such facilities as World Wide Web and video and desktop conferencing. The quality of delivery of instruction is standardized as they would be non variation in presentation. Students are given the opportunities not only to learn according to their pace but also to collaborate with both his course mates and lecturers/instructors even beyond lecture period (idea group Inc, 2006). Al Hashim, Sankaran \& Weiss (2003) in supporting the use of IT in classrooms opine that it leads to expansion in the markets of schools, enable them to adopt and respond to changes and requirements in the global market place, support training of teams with different cultural and functional standpoints by encouraging them to partake and work together. Continuing, IT makes time and space elastic for both the teachers and students to utilize educational materials, tastes users of educational content and provides students with the freedom to take their initiatives. One of the values/relevance of IT to the teaching of accounting is the use of accounting software which is application software that records and processes accounting transaction a modules like accounts payable and receivable, payroll and trial balance. Other software include spreadsheet which is used to do anything that you would normally do with calculator, pencil and columnar scratch pad. It is designed for the easy evaluation of data in the form of words, numbers of groups.

Painham (2001) said his goal in teaching accounting in tertiary institution is to make his students become effective learners by promoting deep learning through the use of accounting software (spreadsheet). Noe (2000) identifies quick book as software which manages payroll, inventory, sales and monitor expenses, create invoices and reports. It also enables charts to be created of accounts receivable, subsidiary and general ledgers and financial statements. Correct accounting software enables students to know how to create custom vouchers, multiples sales account, send reports and documents through e-mail. To deliver accounting course using IT, Absel-Azim (2006) highlighted specific active learning techniques. These include engaged learning cooperative learning, case based learning and project based learning. According 
to him students take the driver's seat in the learning process. They are required to discuss home assignment at the beginning of the class, make short presentation of the new topics, take online quizzes at the beginning of some classes. It also enables students to solve assignments and submit them electronically using digital drop box tool of the black board. Students are required to use laptops both in and out of the classroom to get the course materials from the course black boards site, communicate with peers to solve group assignments through the email and with instructor through the digital drop box.

Statement of the Problem: To enhance students understanding in accounting, tools of information technology should be used/adopted. This is so because, accounting softwares have been developed to carry out specific accounting duties like recording, processing and managing payroll, inventory, sales invoices and expenses etc. The worry is that despite the availability of the automated accounting instructions, our tertiary institutions are miles apart from their usage in teaching students in this globalized world.

Purpose of the Study: Since the traditional passive chalk-talk approach of delivery accounting instructions has not got students to participate actively in class and has been deemed to be not very effective, the purpose of this study is to provide an understanding of the usefulness/relevance of IT and elearning in the improvement of students learning and to determine whether the relevance are adoptable to the teaching and learning of accounting.

\section{Research Questions}

- Do students find it difficult to understand accounting courses without information technology?

- Does IT/e-learning improve/enhance knowledge in accounting principles and skills?

- Does IT/e-learning enhance individualized learning

- Does IT/e-learning create flexible time and space for users

- What difficulties are encountered by the students in the learning of accounting using IT/elearning approach

- Does IT/e-learning reduce cost and expand market.

Hypothesis: There is no significant difference between the mean ratings of business education students and the business educators on the usefulness of IT/e-learning tools in the teaching of accounting courses in tertiary institutions in Edo/Delta State.

\section{Methodology}

The population for the study consisted of all final year students and lecturers in accounting education of colleges of education and polytechnics in Edo/Delta States. The study made use of randomly selected 150 final year students and 30 lecturers. Structured questionnaire of 16 items was used for data collection. This was validated by two experts in education research and measurement. Cronbach coefficient alpha formula was used to analyze the data collected for reliability. Coefficient obtained for the instrument was 0.91. Of the 180 questionnaires administered through the research assistants and personal contacts, 175 successfully completed and returned. The research questions were analyzed using mean and standard deviation. The null hypotheses were tested using t-test. Items that attracted mean rating of 3.5 and above on the five point Likert scale were regarded as agreed but item that attract less than 3.5 were regarded as disagreed. The t-test was used at 0.05 level of significance with 173 as degree of freedom. The decision rule is if the calculated $t$-value is less than the table value, accept the null hypothesis but if the calculated $t$-values is equal or greater than the table value, reject the null hypothesis.

\section{Results of the Data Analysis}

The results in the table below shown homogeneity in response among the respondents. In respect of the usefulness of IT/e-learning tools to the teaching of accounting courses. The result suggests that there is a need for introduction of IT /e-learning in the teaching of accounting in our schools. The result of the t-test shows that the calculated t-test apart one value rating all were more than the critical t-value of 1.96 at 0.05 level of significance and 173 degree of freedom based on the analysis the null hypothesis was rejected. 
Table 1: Results of t-test

\begin{tabular}{|c|c|c|c|c|c|}
\hline $\mathbf{S} / \mathbf{N}$ & $\begin{array}{l}\text { Responses of the business education Lecturers and } \\
\text { business students on the usefulness of IT tools to } \\
\text { teaching of accounting course }\end{array}$ & $\mathbf{X}$ & SD & t-test & Rank \\
\hline 1 & $\begin{array}{l}\text { Use of IT tools will improve students' learning in } \\
\text { accounting principles and practice }\end{array}$ & 4.059 & 1.41 & 2.455 & A \\
\hline 2 & $\begin{array}{l}\text { Use of IT tools will enhance students individualized } \\
\text { learning at their own pace }\end{array}$ & 4.22 & 1.12 & 8.814 & A \\
\hline 3 & $\begin{array}{l}\text { Users IT tools will bring about standardization of quality } \\
\text { of instruction in accounting }\end{array}$ & 3.655 & 0.384 & 4.586 & A \\
\hline 4 & $\begin{array}{l}\text { Students encounter difficulties in learning accounting } \\
\text { when using IT }\end{array}$ & 4.316 & 0.732 & 4.553 & A \\
\hline 5 & $\begin{array}{l}\text { IT creates flexible time and space for both lecturers and } \\
\text { students }\end{array}$ & 4.585 & 0.805 & 8.591 & A \\
\hline 6 & Use of IT reduces cost and expand markets & 4.422 & 1.044 & 0.368 & A \\
\hline
\end{tabular}

Findings: The following findings were made

- That IT/e-learning delivery approach will improve students' learning in accounting

- IT/e-learning enhances individualized students leaning

- IT/ e-learning brings about standardization of the quality of instruction of accounting principles

- Students encountered difficulties in IT/ e-learning accounting without IT

- IT/ e-learning reduces cost and expands market

- Most lecturers lack the knowledge/ skills needed to use the IT facilitate to teach

\section{Conclusion}

In Edo/Delta states many schools have not started to use IT /e-learning delivery approach to impact knowledge to their students particularly in accounting education inspite of its usefulness. This is connected to that fact that most schools do not want to embark on it because of the colossal sum of money it would cost management. Besides, the usefulness of IT /e-learning in teaching accounting courses are not known to most of them.

Recommendations: The following recommendations were made

- Awareness of the usefulness of IT/e-learning approach in the teaching and learning process of accounting courses should be made known to both students lecturer in accounting.

- Tertiary institutions in the states should adopt it as a mode of instruction delivery.

- Workshops, symposia should be organized for lecturers to be able to know or acquire the skills of usage of the IT/e-learning tools i.e. training the trainers workshops should be organized.

- Student's curriculum should be incorporated into it and the how of IT utilization should be taught to them.

- $\quad$ Cyber-café should be opened in every school to cope with the need for use of the I.T tools

\section{References}

Absel-Azim M. H. (2006). The use of technology to improve the delivery of advanced accounting courses in the United Arab Emirates University. Journal of College Teaching and Learning, 3(3), 1-4.

AI Hashim, D., Sankaram, S. \& Weiss, E. (2003) the high-tech global accounting classroom in the $21^{\text {st }}$ century. Journal of American Academy of Business, 3(1), 21 - 30 Neo.

Akpotohwo, F. C. \& Ugeh, C. H. (2007). Student rating educational quality provided by different delivery modes in business and information technology education programme. Business education journal, 6(1), 221.

Al-Soraiey-Alqahtani-Awadh, A. Y. (2010). The effectiveness of using e-learning, blended learning and traditional learning on students' achievement and attitudes in a course on Islamic culture: An experimental study. Durham theses, Dusham University. Available at Durham E-thesis Online http://e-theses.dat.ac.uk/817

AlCPA. (1999). fostering changes in curriculum and teaching methods. Journal of accounting (online) of available htt://www.aicpa. 
Amahi, F. U. 0 \& Uge, B. O. (2004). Introduction to Financial Accounting a simplified approach, Agbor Bridgeo Press.

Ashraf, M. (2004). A critical look at the use of group projects as a pedagogical tool. Journal of Education for Business, 79(1), 2130216.

Bruff, C., Dean, A. \& Nolan, J. (2004). Quality assessment of learning and satisfaction in web-based and lecture courses. Journal of Education Computing Research, 28(3), 198-191.

David, J. S., McGracken, H. \& Reckers, P. M. J. (2003). Integrating technology and business process analysis into introductory accounting courses. Issues in Accounting Education, 18(4), 417 - 477

Idea group Inc. (2006). Using IT in accounting education Journal of cases a information Technology 8 (3) 71-87 July- September, URL - htt://www.idea.group.come

Iheonunekwu, S., Onyinye, E. \& Nweze, P. U. (2008). Reforming the delivery system in business education through information and communication technology (ICT). ABEN Book of Reading, 1(8) 121-126.

Khan, B. (2005). Managing e-learning strategies: design, delivery, implementation and evaluation. Hershey, IA, USA: Idea group Inc.

Oliver E. C. \& Chapman, R. J. (1993). Data processing and information technology London: DP publications Limited

Painham, J. (2001). Lifelong learning a model for increasing the participation on non-traditional adult learner.

Schenes, R., Leinhardt, G., Smith, J. \& Cho, K. (2005). Replacing lecture with web-based courses materials. Journal of Educational computing Research, 32(1), $1-26$.

Smith, A. D. \& Rupp, W. T. (2004). Management Implications of Computers based online/face - to - face business education; A case study. Online Information review, 28(2), 100-109. 